\title{
Linking Organizational Justice to Turnover Intention: Organization-Employee Relationship Quality Mediator
}

\author{
Sarfilianty Anggiani \\ Management Department, Faculty of Economic and Business \\ Trisakti University \\ Jakarta, Indonesia \\ sarfilianty@trisakti.ac.id
}

\author{
Tri Wiyana \\ Hotel Management Department, Faculty of Economics and \\ Communication \\ Bina Nusantara University \\ Jakarta, Indonesia \\ triwiyana@binus.edu
}

\begin{abstract}
It is evident from the past research that employees who perceive the organizational justice and organizational-employee relationship quality are negatively associated with turnover intention, the employees tend to leave the organizations and start their professional career in other organizations where they feel comfortable and organization policies as fair and just. This study analyzes the effect of organizational justice variables on turnover intention mediated by the Oganizational-employee relationship quality at three-star hotels in Jakarta, with questionnaires being distributed to 270 employees. Structural equation model was used to analyze the data. Organizational justice berpengaruh negatif terhadap turnover intention melalui organization-employee relationship quality. Hal ini ditandai dengan hasil perhitungan statistic sebesar $\mathbf{- 0 , 8 2 2}$ yang menunjukkan terdapat pengaruh negatif dari organizational justice terhadap turnover intention yang dimediasi oleh organization-employee relationship quality.
\end{abstract}

Keywords-Hospitality Industry, Organizational Justice, Turnover Intention, Oganizational-Employee Relationship Quality

\section{INTRODUCTION}

The field of tourism and hospitality is a fast changing one. Because tourism is not a single discipline but is connected to many other aspects of life it is constantly changing. Tourism has a connection to many other disciplines including politics, religion, agriculture, economics, environment, health, finance, transport, society, immigration, and education just to name a few. All of these fields of human are constantly changing and changes in one field will impact on other fields and hence also on tourism [1]. The world of travel and hospitality has entered a new era of growth and transformation. Global business travel spending hit a record-breaking \$1.2 trillion in 2015 [2].

In hotel industry organizations the role of human resource management is very important. Employees are assets of the organization and company communicators which in the long run are important for the survival of the organization. Employees are the backbone of any business success and therefore, they need to be motivated and maintained in organization at all cost to aid the organization to be globally competitive in terms of providing quality products and services to the society [3]. The organization must better identify and understand the possible causes that predict turnover intention. According George [4] it's a great concern for organizations to retain the professional workers and still this issue has not been resolved. Such businesses need to take into account organizational commitment and job satisfaction among their staff as these qualities are believed to be closely tied to staff turnover [5].

Human resource managers should explore strategies to grow the organizational environment with organizational Justice so that there are conditions where employees feel involved in dialogue with the organization, the distributive justice tend to be the strongest contributor of employee job performance compared to procedural justice and interactional justice [6]. Improved treatment of organizational and developing mutual trust and understanding between management and workers lead to the organizational commitment [7]. Other factors that can affect Turnover Intention are Organization-Employee Relationship Quality. Organization-Employee Relationship Quality in an organization is very important, provide understanding that how these variables affect the turnover intention and how to reduce turnover rate [8]. There is a significant relationship between perceived supervisor support, perceived organizational support and organizational commitment towards employees' turnover intention [9].

Turnover intention mostly tends to have an adverse impact on the organization, both in terms of cost and in terms of time. Turnover Intention that occurs continuously and continuously can reduce the level of productivity of the company. Job satisfaction and turnover intention of these individuals could have long term implications since it relates to mitigating the shortage of superintendent candidates available to fill the growing number of vacancies as well as recruitment, retention, and increased work productivity of these staff [10]. This also applies to all three-star hotels in Jakarta. In developing its strategy to be able to compete in the service industry market in Indonesia, three-star hotels must have adequate resources both equipment and technology and human resources as the main drivers in hospitality service providers. Therefore, the role and cooperation of employees in three-star hotels is very important so that internal managers need to find ways to maintain good relationships with employees by paying attention to the Organization-Employee Relationship Quality and Organizational Justice factors to reduce Turnover Intention. Based on the background of the above problems, the title of this study is " Linking 
Organizational Justice to Turnover Intention: OrganizationEmployee Relationship Quality Mediator (Case study at Three Star Hotels in Jakarta).

\section{LITERATURE REVIEW}

\section{A. Trends in Hospitality Industry}

As with other forms of research, hospitality research has become commodified by universities, has been much influenced by changes in greater availability of analytical software packages, and been much influenced by new challenges in the industry, notably globalization and the rise of Asia [11]. Consumer and business driven tech-enabled shifts are only part of the 2025 scenario for hotels [12]. The globally hospitality and tourism activities are increasing by leaps and bounds hence a proportionate increase in expenditure both for tourists and service providers [13]. Many tourists are taking their tablets, computers and phones on vacation with them and technology has decreased customer service in the tourism industry. Most can make their flight reservations, reserve a hotel room and make dinning and tourist attraction reservations [14]. Today we see that an increasing amount of developers and buyers are convinced that

Millennials will come to dominate hotel demand in the following years; as such, the hotel sector should be ready to respond to the development of lifestyle and soft brands according to the project's business plan [15].

\section{B. Concept of Organizational Justice}

Justice is recognized as an action or decision that is understood to be morally right on the basis of ethics, religious, fairness, equity or law [16]. Organizational justice consists of three dimensions, namely, distributive, procedural and interactional justice. Organizational justice affects not only organizational performance, but to a large extent, also determines the economic wellbeing of an employee [17]. Organizational justice, first postulated by Greenberg in 1987, refers to an employee's perception of their organization's behaviors, decisions and actions and how these influences the employee own attitudes and behaviors at work [18]. Justice research has become increasingly multilevel, as research has begun to explore how shared perceptions of justice form within work groups and organizations (justice climate) and has considered how justice perceptions and reactions vary across cultural groups (e.g., organizational and national cultures).

In literature organizational justice usually examined with three dimensions. These are distributive, procedural and interactional justice. While theorists explain the concept of organizational justice, they taken into consideration that distribution justice that means the distribution of gains, procedural justice that means the distribution of transactions, and interpersonal and informational justice caused by interpersonal interaction. The distributive justice centers on the belief of people who receive fair work outcomes in form of pay, recognition and other rewards. It is the perceptions of employees over equitable gains received from organizational resources, rewards and penalties (Fitzs \& Gerald, 2002; Nirmala \& Akhilesh, 2006; Blakely et al, 2005; [19]. In support of procedural justice theory is a good deal of evidence from both the United States and abroad that the police are viewed as legitimate - i.e. seen as an appropriate and proper institution that is morally entitled to use its legal authority and have its directives obeyed and decisions accepted - in large part when officers are seen to act in procedurally just ways (Jackson et al., 2014; Bradford et al. 2014; Murphy et al. 2016; [20]. Interactional justice is the nature of inter-individual behavior where an individual is responsible preliminary and after the decision process. Interactional justice concentrates on relational treatment received during decision process and in addition systems which incorporate different individual practices upon social affectability, for example, regard, trustworthiness, pride, courteousness shown by the originator of equity toward beneficiary of equity (Cropanzano, Prehar and Chen, 2002; [6].

\section{Organization-Employee Relationship Quality}

The individual evaluation of fairness provides a cue regarding their relationship with their organizations (Bladerand Tyler, 2003; [21]. The supervisor subordinate relationship quality was positively related to both the amount and quality of information employees received from their immediate supervisor. In addition, employee proportions of information peer relationships were negatively related, and their proportions of collegial peer relationships were positively related, to the quality of information they received from their co - workers [22]. Among the three aspects of employee relationship quality, commitment showed the strongest unit contributions towards customer satisfaction [23].

The older employees experienced better exchange relationships with their supervisors, and that this mediated the relationship between age and job satisfaction [24]. The quality of the relationship between supervisors and service employees is a significant factor [25]. They are general employees or leadership employees, the employee - superior relationship was the principal factor that influenced EWB [26]. Employee organizational relation is dynamic and can be measured using perceptions of either or both parties regarding four indicators representing the quality of Employee organizational relation or "relationship outcomes", i.e., satisfaction, trust, commitment, and control mutuality (Grunig and Huang, 2000:42; [27].

\section{Turnover Intention}

Studying turnover intention is pretty much relevant as it can help organizations tackle turnover related problems, so that can predict turnover intention [28]. The job embeddedness not moderate the relationship of turnover intentions and organizational justice [4]. Employee turnover in organizations has thus, received substantial attention from both academics and managers. The tourism industry which finds itself in this sector and being the world's fastest growing industry (Baum, 2002; [29]. Turnover is the movement of workers in and out of a company, voidable voluntary turnover can be caused by various reasons such as salary, work condition, superior, or other better organization, when unavoidable voluntary turnover can be caused by change in career path or family reasons (Zeffane, 2003; [30]. Leadermember exchange was found to have a significant negative relationship with mobbing and employee turnover intentions. Mobbing, on the other hand, had a significant positive relationship with employee turnover intentions and mediated 
the relationship between leader-member exchange and employee turnover intentions [31].

\section{E. Organizational Justice and Turnover Intentions}

Considering the prominent role of organizational justice in the personnel's intention to stay or leave and due to the high costs of recruiting and training new staff, managers should pay especial attention to justice and provide their employees' satisfaction and stability in their organizations by creating a positive mindset in them [32]. Organizational justice and organization-employee relationship quality are negatively associated with turnover intention [21]. Organizationemployee relationship quality as a predictor of employee turnover intention and a mediator between authoritarian organizational culture and turnover intention [21]. Employees working in a healthcare organization demonstrate that perceptions of client-focused fairness uniquely predict supervisor ratings of employee organizational citizenship behavior toward clients and that perceptions of workgroupfocused justice uniquely predicts organizational citizenship behavior toward workgroups, client-focused justice perceptions uniquely predict employee turnover intention [33].

From the practical perspective, employees of an organization will reflect positive behavior and productivity if they perceive their organization as fair and just in its procedures and distribution systems. Enhancing organizational justice results in improved outcomes from employees [34]. The job satisfaction and organizational commitment significantly affected turnover intention through leadership behavior [35]. Managers need to acknowledge the importance of examining the factors that reduce the turnover intentions of the employees and improve the commitment level for their employees [36].

As stated earlier, employees who intend to leave the organization have a low level of interest in their current work. Hospitality staff work in high pressure and their work routines are tight compared to other employees. Therefore, to understand this behavior in the hospitality sector, this research was conducted. In addition to employee perceptions of organizational justice toward turnover intentions and the role of moderating the organizational-employee relations quality from job insertion were also analyzed.

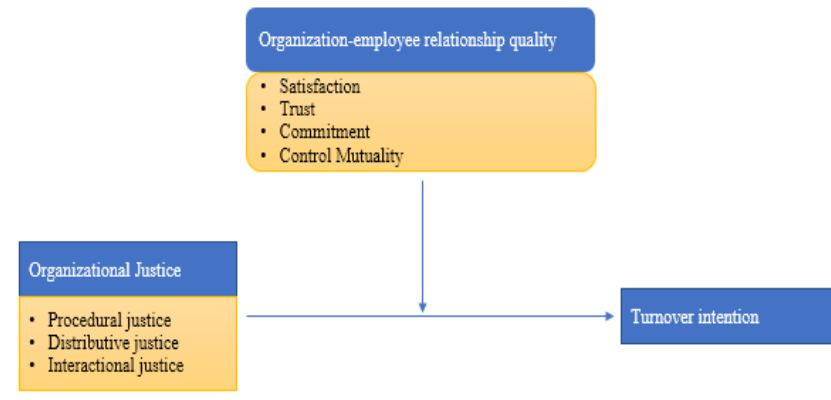

Figure 1. Conceptual Framework

Source: research model (2018)

Hypothesis Model:

H1: Organizational Justice has a positive effect on Organization-Employee Relationship Quality
H2: Organization-Employee Relationship Quality has a negative effect on Turnover Intention

H3: Organizational Justice negatively affects Turnover Intention

H4: Organizational Justice has a negative effect on Turnover Intention mediated by OrganizationEmployee Relationship Quality

\section{MATERIALS AND METHODOLOGY}

\section{A. Sampling Technique}

The research method used in this study is a method of data collection by distributing questionnaires, were distributed to 270 employees of three-star hotels in Jakarta namely by means of purposive sampling which is criticized as having worked in the same hotel for more than 1 year and frontliner position levels (receptionists, restaurant and security waiters) and for three-star hotel employees in Jakarta consisting of:

.1 Ibis Hotel Jakarta

.2 Amaris Hotel Jakarta

.3 Jakarta Fave Hotel

.4 Whiz Hotel Jakarta

.5 Hotel MaxOne Jakarta

\section{B. Measurement}

Data was collected using questionnaires. All the scales were adapted from past literature. Response was taken on fivepoint Likert Scale starting from 5=strongly disagree to $1=$ strongly agree.

\section{1) Organizational Justice}

Statements for Organizational Justice are developed from the research of [21] which consists of six statement items:

Company procedures and guidelines are very fair

Relying on the company because it has a fair policy

Always get information about things that are done by this company

The company always informs the results of performance in good or bad conditions

The company treats with dignity and respect

In making decisions, the company adheres to the principle of openness to all employees

\section{2) Organizational-Employee Relationship Quality}

In this study the mediating variable is an OrganizationalEmployee Relationship Quality consisting of four dimensions: Mutuality Control, Trust, Commitment and Satisfaction (Grunig and Huang, 2000:42; [27] which consists of four statement items:

Trust is the level of trust of one party to open themselves to the
other party
Control mutuality is the extent to which parties agree on who has
the legitimate power to influence each other

Commitment is the extent to which one party believes and feels that the relationship is worth keeping 
Satisfaction is the extent to which employees are satisfied with their relationship with the organization

Source: theory analysis, 2018

\section{3) Turnover Intention}

Statements for Turnover Intention were developed from research (Zeffane, 2003; [30] which consists of three statement items:

\begin{tabular}{l}
\hline Desiring to switch from my job in 2-3 years \\
\hline Thinking of resigning to work \\
\hline Looking for new jobs if possible
\end{tabular}

\section{RESULTS AND DISCUSSION}

Majority of the respondents were male that is $69.9 \%$ and rests were females. Participants ranged from 25 to 54 years of age with a mean age of 29 years having a mean experience of 3.2 years of total job experience of the participants. The education level of the respondents shows that $64.4 \%$ respondents are associates degree holders, $23.4 \%$ are bachelor degree, and rest were senior high school.

Data analysis methods used by looking at the research objectives are as follows: (1) To analyze Organizational Justice in Three Star Hotels in Jakarta using descriptive statistics, namely by calculating the average answers of respondents; (2) To analyze the Organization-Employee Relationship Quality of Three-Star Hotels in Jakarta using descriptive statistics by calculating the average answers of the respondents; (3) To analyze the Three Star Hotel Turnover Intention in Jakarta. by using descriptive statistics by calculating the average answers of the respondents; (4) To analyze the effect of Organizational Justice on Turnover Intention mediated by Organization-Employee Relationship Quality using structural equation model (SEM); (5) Test the suitability of the formation of the conceptual framework (Goodness of Fit Model) which shows the formation of the influence of Organizational Justice on Turnover Intention mediated by the Organization-Employee Relationship Quality.

Table 1. The Goodness of Fit Model

\begin{tabular}{lccc}
\hline $\begin{array}{c}\text { Goodness of } \\
\text { fit index }\end{array}$ & $\begin{array}{c}\text { Criteria } \\
\text { (cut-off } \\
\text { value) }\end{array}$ & $\begin{array}{c}\text { Indicator } \\
\text { Value }\end{array}$ & Conclusion \\
\hline $\begin{array}{l}\text { Chi-Square } \\
\left(\mathrm{X}^{2}\right)\end{array}$ & $\begin{array}{c}\text { Approach } \\
0\end{array}$ & 207,705 & $\begin{array}{c}\text { No Goodness } \\
\text { of Fit }\end{array}$ \\
\hline Probability & $\geq 0,05$ & 0,000 & $\begin{array}{c}\text { No Goodness } \\
\text { of Fit }\end{array}$ \\
\hline NFI & $\geq 0,90$ & 0,913 & $\begin{array}{c}\text { Goodness of } \\
\text { Fit }\end{array}$ \\
\hline IFI & $\geq 0,90$ & 0,938 & $\begin{array}{c}\text { Goodness of } \\
\text { Fit }\end{array}$ \\
\hline TLI & $\geq 0,90$ & 0,921 & $\begin{array}{c}\text { Goodness of } \\
\text { Fit }\end{array}$ \\
\hline CFI & $\leq 0,90$ & 0,937 & $\begin{array}{c}\text { Goodness of } \\
\text { Fit }\end{array}$ \\
\hline RMR & $\leq 0,10$ & 0,115 & $\begin{array}{c}\text { No Goodness } \\
\text { of Fit }\end{array}$ \\
\hline RMSEA & 026 & Fit \\
\hline
\end{tabular}

Source: processing data using AMOS
The results of the goodness of fit test can be concluded that the NFI, IFI, TLI, CFI and RMR approaches are used to conclude the fit model, so that the theory hypothesis is continued.

Hypothesis testing is done using the Structural Equation Model (SEM) method with the help of AMOS software. The hypothesis was tested at a significance level of 0.05 and a $95 \%$ confidence level.

Table 2. Hypothesis Test Results

\begin{tabular}{cccc}
\hline Hypothesis & $\begin{array}{c}\text { Coeff. } \\
\text { Beta }\end{array}$ & P-value & Result \\
\hline H1: Organizational Justice & & & Ho \\
has a positive effect on & & & \\
$\begin{array}{c}\text { Organization-Employee } \\
\text { Relationship Quality }\end{array}$ & & &
\end{tabular}

H2: Organization-Employee
Relationship Quality has a
negative effect on Turnover
Intention

$-0.899 \quad 0.000$

H3: Organizational Justice

negatively affects Turnover Intention

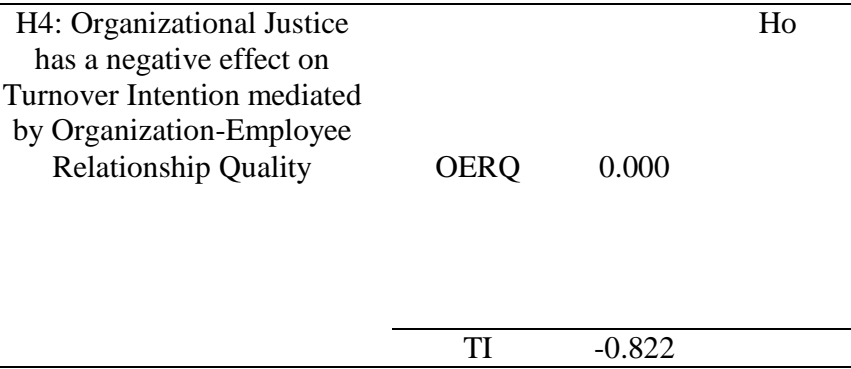
Source: processing data using AMOS

Based on the results of testing the first hypothesis, it can be concluded that there is a positive influence of Organizational Justice on Organization-Employee Relationship Quality of $0.000<0.05$, then Ha is accept and Ho is rejected, with a beta value of 0.944 . The results of this study support the results of previous studies conducted by [21]. This shows that Organizational Justice has a positive influence on the Organization-Employee Relationship Quality, because Organizational Justice plays an important role as a motivator to foster a sense of trust and satisfaction for employees in the organization so Organizational Justice can also create good relationships between leaders and employees when working within the company and create positive attitudes and behaviors from within the employee such as employee commitment when working inside the company so that it can 
help the company to achieve the company's common goals and increase the company's productivity to the full.

Based on the results of testing the second hypothesis, it can be concluded that there is a negative influence of Organization-Employee Relationship Quality on Turnover Intention of $0.000<0.05$, then Ha is accept and Ho is rejected, with a beta value of -0.899 . the results of this study support the results of previous studies conducted by (Grunig and Huang, 2000:42; [27]. This shows that the OrganizationEmployee Relationship Quality has a negative influence on Turnover Intention, because in a work environment, Organization-Employee Relationship Quality that is applied to the company effectively, will make an employee feel close and get support from the organization so as to create a situation where more mutually influence and understand each other and make employees easier to make adjustments in the company and ultimately can improve employee performance and profits for the company.

Based on the results of testing the third hypothesis, it can be concluded that there is no negative influence of Organizational Justice on Turnover Intention of $0.210>0.05$, then $\mathrm{Ha}$ is reject and $\mathrm{Ho}$ is accepted, with a beta value of 0.345 . the results of this study do not support the results of previous studies conducted by [21]. This shows that Organizational Justice does not have a negative influence on Turnover Intention or has no effect on Turnover Intention, this is not in line with the research of Kim (2007) who found a negative relationship between Organizational Justice and Turnover Intention and does not correspond to the opinion that Organizational Justice will be linked negative with Turnover Intention found in previous studies [4]. Therefore, from the previous findings, [21] assume that how employees perceive interaction with an organization with Organizational Justice can be related to Turnover Intention, and [21] find that Organizational Justice is a predictor significant for Turnover Intention with a value of $\beta=-0.274$, p-value of $0.001<0.05$ (alpha 5\%).

Based on the results of testing the fourth hypothesis, it can be concluded that there is a negative influence of Organizational Justice on Turnover Intention through Organization-Employee Relationship Quality that is equal to -0.822 , then the results of this test show in accordance with the hypothesis proposed and support the results of previous research conducted by [30]. This shows that Organizational Justice has a negative influence on Turnover Intention through the Organization-Employee Relationship Quality, because with employees' perceptions of Organization-Employee Relationship Quality will make employees feel close to their organization and create conditions where they understand each other and understand each other so it will be easier for employees to foster a sense of trust among their employees in the organization, besides that employees will increasingly love the organization and do not have a bad perception of the organization so that indirectly employees will feel the existence of Organizational Justice from their organization through the well-established Organization Employee Relationship Quality and effective. This employee have the energy to contribute to the company so that it will increase the company's productivity maximally.

\section{CONCLUSION}

Organizational justice has a mean value (average) of 4.49. This shows organizational justice is considered one of the factors that can influence employee perception in the company, to foster a sense of trust and satisfaction for employees in the organization, so as to increase employee work productivity effectively and increase company productivity optimally and can help companies achieve their goals from the company.

Organization-employee relationship quality has a mean value (average) of 4.54. This shows that organizationemployee relationship quality is considered as one of the factors that can influence employee perception in the company, in establishing a good and effective relationship between leaders and employees so as to create positive attitudes and behaviors from within employees such as commitment, satisfaction, trust employees while working within the company and ultimately can improve employee work productivity effectively and increase company productivity to the fullest and can help the company achieve the goals of the company.

Turnover Intention has a mean value (average) of 1.18. This shows the circumstances in which employees never agree, think or intend to switch or quit the company with a variety of factors and certain reasons so that the organization does not need to worry about the existence of turnover intention that can cause various impacts on a company.

Organizational justice has no negative effect on turnover intention. This is indicated by p-value of $0.210>0.05$ (alpha $5 \%$ ) with a beta value of 0.345 , which means that the higher the perception of Organizational Justice is the higher the Turnover Intention perception, then concluded there is no influence of organizational justice on turnover intention. This is not in line with the research of Kim et al., (2017) who found organizational justice a significant predictor of turnover intention with value of $\beta=-0.274, p$-value of $0.001<0.05$ (alpha 5\%), which indicates that employees who have a positive evaluation of organizational Justice will be less inclined to do turnover intention

Organization-employee relationship quality has a negative effect on turnover Intention. This is indicated by $p$-value of $0.000<0.05$ (alpha $5 \%$ ) with a beta value of -0.899 , which means that the higher the perception of organizationemployee relationship quality, the lower the perception of Turnover Intention.

Organizational justice negatively affects Turnover Intention through organization-employee relationship quality. This is indicated by a statistical calculation of -0.822 which shows that there is a negative influence from organizational justice on turnover intention mediated by organizationemployee relationship quality.

Input for managers of human resources three-star hotels in Jakarta: (1) It is better for organizations to continue to maintain organizational justice policies, especially regarding guidelines and procedures that exist in the company by always informing employees about decisions or policies that will affect employee relations with the organization in a company; (2) It is better for organizations to emphasize and enhance the role of internal communication managers in managing employee relations with the organization by listening more to 
what employees say; (3) The organization must have a broader understanding of how to prevent and overcome problems in the company, especially problems when employees think of leaving the organization and looking for new jobs if possible, by always working together and realizing that the input of various parties is very important important.

\section{ACKNOWLEDGMENT}

The authors are grateful to Prof. Farida Jasfar as Director of Doctoral Program Service Management and Hotel Management Lecturer who provides the facilities required for the preparation of this paper.

\section{REFERENCES}

[1] T. Bauer, "Trends and issues in the tourism and hospitality industry," School of Hotel and Tourism Management, The Hong Kong Polytechnic University and PSHE Section, Hongkong, 2014.

[2] Global Business Travel Association press release, "2017 travel and hospitality industry outlook," Deloitte center for industry insight , 2017

[3] N. Azela, B. Nasrudin, Hasrifafidee, B. Hasbollah, D. and B. B. Simpong, "Types, Cause And Effects of Hotel Staff Turnover Intention: A Litersture Review From Hotel Industry in Malaysia," International Journal of Management and Applied Science, vol. 3, no. 3, pp. 120-122, March 2017.

[4] S. Arif, "Impact of Organizational Justice on Turnover Intentions: Moderating role of Job Embededdness," SEISENSE Journal of Management, vol. 1, no. 2, May 2018.

[5] D. A. Yousef, "Organizational commitment, job satisfaction and attitudes toward organizational change: A study in the local government," International Journal of Public Administration, pp. 77 88,2017

[6] R. Khrisnan, K. W. Loon, N. A. F. Ahmad and N. A. S. Yunus, "Examining the Relationship between Organizational Justice and Job Performance," International Journal of Academic Research in Business and Social Science, vol. 8, pp. 467-477, 2018.

[7] B. Gimire, "Relationship among Trust, Justice and Organizational Commitment at Hospitals in Nepal," Pravaha Journal, pp. 31-38, 2018.

[8] I. Saeed, M. Waseem, S. Sikander and M. Rizwan, "The relationship of Turnover intention with job satisfaction, job performance, Leader member exchange, Emotional intelligence and organizational commitment," International Journal of Learning \& Development, vol. 4, pp. 242-256, 2014.

[9] A. Kalidass and A. Bahron, "The Relationship between Perceived Supervisor Support, Perceived Organizational Support, Organizational Commitment and Employee Turnover Intention," International Journal of Business Administration, pp. 82-89, 16 September 2015.

[10] J. O'Connor, "The Impact of Job Satisfaction on the Turnover Intent of Executive Level Central Office Administrators in Texas Public School Districts: A Quantitative Study of Work Related Constructs," Education Science, pp. 1-13, 7 May 2018.

[11] C. Ryan, "Trends in hospitality management research: A personal reflection," International Journal of Contemporary Hospitality Management, pp. 340-361, April 2015.

[12] Cognizant, "The Road To 2025: Hospitality in the Digital Era," Cognizant, 2017.

[13] P. Brako and S. T. Joseph, "Emerging Trends in Hospitality and Tourism in India," 3rd National Seminar on Hospitality and Tourism Management, November 2016.

[14] S. Scott, "Growing Trends in the Tourism and Hospitality Industry," Tourism \& Hospitality, vol. 4, no. 3, 11 July 2015

[15] H. Gonzales, M. Straneva, J. N. Sanchez and R. Karver, "Hospitality Trend 2017: Observation From The EY Mexico City Hospitality Roundtable," EY Building a Better Working World, Mexico, 2017.

[16] V. M. Pekurinen, M. Valimaki, P. Salo, M. Kivimaki and J. Vahtera, "Organizational justice and collaboration among nurses as correlates of violent assaults by patients in psychiatric care," Psychiatr. Serv., pp. 490-496, 2017.
[17] T. F. Yean and A. A. Yusof, "Organizational Justice: A Conceptual Discussion," Procedia - Social and Behavioral Sciences 219, pp. 798803, 2016.

[18] Hrzone, "hr-glosarry," 21 August 2018. [Online]. Available: https://www.hrzone.com/hr-glossary/what-is-organizational-justice.

[19] S. O. Timinipere, E. K. Agbaeze, A. Ogbo and N. U. C, "Organizational Justice and Turnover Intention among Medical and Non-Medical Workers in University Teaching Hospitals," Mediterranean Journal of Social Sciences, vol. 9, no. 2, March 2018

[20] R. Trinkner, J. Jackson and T. R. Taylor, "Bounded authority: expanding 'appropriate' police behavior beyond procedural justice," LSE Research Online, pp. 1-20, 2018.

[21] S. Kim, L. Tam, J. N. Kim and Y. Ree, "Determinants of employee turnover intention: Understanding the roles of organizational justice, supervisory justice, authoritarian organizational culture and organization-employee relationship quality," Corporate Communications: An International Journal, pp. 308-328, 2017.

[22] P. M. Sias, "Workplace Relationship Quality and Employee Information Experiences," Communication Studies, pp. 375-395, 2005.

[23] S. D. Rusdi, N. Achim and W. E. Wan Rasyid, "Employee Relationship Quality and Customer Satisfaction: The Case of Halal Products Supplier at Elhajj Products SdnBhd," Journal of Applied Environmental and Bilogical Science, pp. 35-39, 11 May 2016.

[24] F. J. Gallert, "The influence of age on perceptions of relationship quality and performance in care service work teams," Emerald Insight, pp. 44-60, 2011

[25] R. F. Wharton and Y. Brunetto, "Organisational relationship quality and service employee acceptance of change in SMEs: A social exchange perspective," Journal of Management \& Organization, pp. 114-125, 2007.

[26] H. Chen, J. Wei, K. Wang and Y. Peng, "Does Employee Relationship Quality Influence Employee Well - Being? An Empirical Analysis Based on Manufacturing and Service Industries," Wiley Online Library, 1 June 2016.

[27] S. B. Tastan, "The Impact of Employee-Organizational Relationship on Individual's Behavioral Outcomes of Task-Related Performance, Contextual Performance and Intention Turnover: An Evalutaion With Ssocial Exchange Theory," International Journal of Business and Management Studies, vol. 6, no. 1, pp. 42-53, 2014.

[28] S. Rautela and S. Mavale, "Exploring Factors of Employee Turnover Intention - An Overview," IJEMR, vol. 6, no. 5, pp. 1-6, May 2016.

[29] V. K. Asimah, "Factors That Influence Labour Turnover Intentions in The Hospitality Industry in Ghana," African Journal of Hospitality, Tourism, and Leisure, vol. 7, no. 1, pp. 1-11, 2018.

[30] N. Silaban and T. Y. Rahmat Syah, "The Influence of Compensation and Organizational Commitment on Employees' Turnover Intention," IOSR Journal of Business and Management, vol. 20, no. 3, pp. 1-6, March 2018.

[31] S. M. Yildiz, "An empirical analysis of the leader-member exchange and employee turnover intentions mediated by mobbing: evidence from sport organisations," Economic Research-Ekonomska Istraživanja, pp. 480-497, 2018.

[32] S. Tourani, O. Khosravizadeh, A. Omrani, M. Sokhanvar, E. Kakeman and B. Najafri, "The Relationship Between Organizational Justice and Turnover Intention of Hospital Business Nurses in Iran," Mater Sociomed, pp. 205-209, 25 May 2016.

[33] C. M. Harris, J. J. Lavelle and G. C. McMahan, "The effects of internal and external sources of justice on employee turnover intention and organizational citizenship behavior toward clients and workgroup members," The International Journal of Human Resource Management, 19 February 2018

[34] X. Pan, M. Chen, Z. Hao and W. Bi, "The Effects of Organizational Justice on Positive Organizational Behavior: Evidence from a LargeSample Survey and a Situational Experiment," Frontiers in Psychology, 10 January 2018.

[35] S. Terason, "Managerial Turnover Intention As A Result of Leadership Behavior, Job Satisfaction and Organizationa Commitment: Evidence From Cross-National Fitness Enterprises in Thailand," Academy of Strategic Management Journal, vol. 17, no. 1, pp. 1-12, 2018.

[36] A. A. Al-khrabsheh, M. Abo-Murad and I. Bourini, "Effect of Organisational Factors on Employee Turnover Intention: An Empirical 
Study of Academic Professionals at Jordanian Government Universities," International Journal of Human Resource Studies, vol. 8, no. 2, 2018.
[37] R. Khrisnan, K. W. Loon, N. A. Farihah and N. A. S. Yunus, "Examining the Relationship between Organizational Justice and Job Performance," Interantional Journal of Academic Research in Business \& Social Science, pp. 466-477, 25 February 2018. 